\title{
Intra-articular entrapment of an avulsed common peroneal nerve following atypical knee fracture- dislocation
}

\author{
Fiachra R Power 이, ${ }^{1}$ Kunal Mohan, ${ }^{1}$ Diane Bergin, ${ }^{2}$ Fintan Shannon ${ }^{1}$
}

'Department of Trauma \& Orthopaedic Surgery, University Hospital Galway, HSE West, Galway, Ireland

2Department of Radiology, University Hospital Galway, HSE West, Galway, Ireland

Correspondence to Dr Fiachra R Power; fiachrapower@rcsi.ie

Accepted 11 April 2021

\section{DESCRIPTION}

A man in his early 30s presented with an atypical fracture-dislocation of his left knee as a result of being ankle tapped while running. He sustained a Moore type 2 knee fracture-dislocation consisting of a posteromedial tibial plateau fracture that extended across to the lateral plateau articular surface and a severe posterolateral corner (PLC) injury, in addition to a common peroneal nerve $(\mathrm{CPN})$ palsy. Both the anterior cruciate ligament (ACL) and posterior cruciate ligament (PCL) were intact. Initial management consisted of a manipulation under anaesthesia and casting in theatre to achieve satisfactory reduction until the soft tissues were suitable to proceed with definitive management.

The patient was subsequently taken to theatre for fixation of his posteromedial tibial plateau fracture, PLC reconstruction and exploration of the $\mathrm{CPN}$. Intraoperative findings included avulsion of

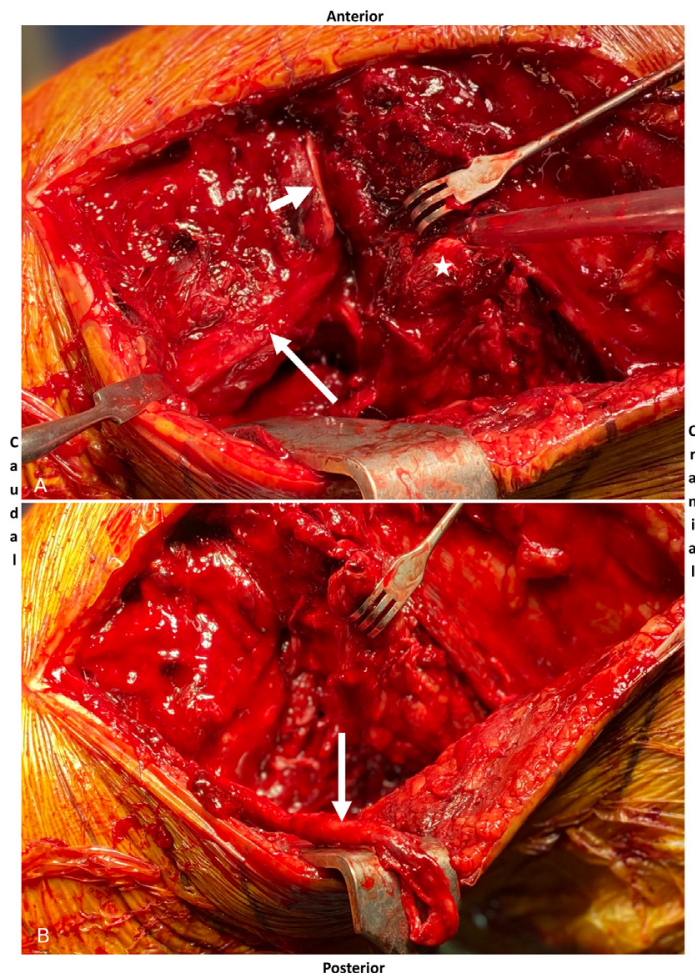

imited 2021. No commercial re-use. See rights and permissions. Published by BMJ.

To cite: Power FR, Mohan K, Bergin D, et al. BMJ Case Rep 2021;14:e242575. doi:10.1136/bcr-2021242575

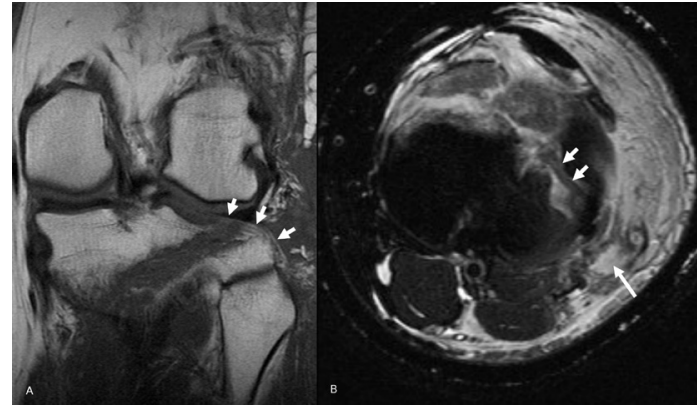

Figure 2 Preoperative MRI knee: Coronal T1 spin echo (A) and axial T2 weighted fat suppressed (B) images demonstrates intra-articular incarceration of the common peroneal nerve (short arrow) inferior to the lateral meniscus. The nerve is recognised by its striated appearance on non-fat saturated image. This is seen in association with complete disruption of soft tissue structures (biceps femoris and fibulocollateral ligament) in the posterolateral corner which are replaced by haematoma (long arrow).

the lateral collateral ligament and biceps femoris tendon off the fibular head and complete disruption of the anterolateral capsule off the proximal tibia. The femoral insertion of the popliteus tendon was intact; however, there was a complete tear through the muscle belly with tendon and muscle incarcerated in the tibial plateau fracture. We were unable to identify the CPN proximally above the knee as per our usual surgical technique. The CPN was identified at the level of fibular neck and could be visualised tracking into the lateral compartment of the knee joint (figure 1). Following fracture fixation and PLC reconstruction the local plastic surgery service performed an end to side anastomosis of the proximal CPN to its avulsion site from the sciatic nerve.

A specialist musculoskeletal radiologist opinion of the post-manipulation MRI demonstrated the pathology seen at the time of definitive surgery, including a striated linear structure recognised as the peroneal nerve which was displaced and trapped in the lateral compartment of the knee beneath the meniscus (figure 2).

The incidence of CPN palsy following PLC injury is approximately $25 \% .^{12}$ Complete nerve discontinuity is, however, only seen in $5 \%{ }^{2}$ to $7 \%{ }^{1}$ of cases. All cases of complete nerve transection were associated with multiligamentous injuries involving ACL, PCL and PLC ruptures. ${ }^{2}$ Traumatic intra-articular peroneal nerve entrapment has only been described 
in the literature once before ${ }^{3}$ in a case with combined ACL/PCL/ PLC rupture without an associated fracture. Our case is unique given the preservation of the cruciate ligaments as well as being the first published case to show corresponding MRI and open surgical findings. Identifying abnormality of neural structures on

\section{Patient's perspective}

My experience of the injury was that it was very painful at the time of the accident and also very painful during my recovery which is to be expected but I was helped with medication to put my pain at ease. The staff were fantastic during my hospital experience and the surgeons were spot on with my surgeries.

\section{Learning points}

- Common peroneal nerve (CPN) palsies associated with posterolateral corner injuries of the knee are relatively common $(25 \%)$, and in some cases may represent complete nerve transection/avulsion (5\%-7\%).

- While exceedingly rare, intra-articular entrapment of an avulsed CPN should be actively looked for both on preoperative review of MRI and intraoperatively in cases of traumatic CPN palsy to allow for appropriate timing and techniques of surgical management.
MRI in the setting of trauma can help guide both the timing and technique of surgical intervention as well as alerting the treating team in advance that the services of a surgeon with the ability to repair or reconstruct peripheral nerves will be required.

\section{Twitter Fiachra R Power @FPower123}

Contributors FS performed the surgery and was assisted by FRP and KM. DB reviewed the imaging. FRP, KM, DB and FS contributed to the conception and design. FRP and DB acquired the data. FRP, KM, DB and FS all contributed to the analysis of the data. FRP drafted the article and FRP, KM, DB and FS revised it critically for important intellectual content. All authors have given final approval of the version published and agree to be accountable for the article and to ensure that all questions regarding the accuracy or integrity of the article are investigated and resolved.

Funding The authors have not declared a specific grant for this research from any funding agency in the public, commercial or not-for-profit sectors.

Competing interests None declared.

Patient consent for publication Obtained.

Provenance and peer review Not commissioned; externally peer reviewed.

\section{ORCID iD}

Fiachra R Power http://orcid.org/0000-0002-0632-1601

\section{REFERENCES}

1 Ridley TJ, McCarthy MA, Bollier MJ, et al. The incidence and clinical outcomes of peroneal nerve injuries associated with posterolateral corner injuries of the knee. Knee Surg Sports Traumatol Arthrosc 2018;26:806-11.

2 Niall DM, Nutton RW, Keating JF. Palsy of the common peroneal nerve after traumatic dislocation of the knee. J Bone Joint Surg Br 2005;87:664-7.

3 Alhoukail A, Panu A, Olson J, et al. Intra-articular peroneal nerve incarceration following multi-ligament knee injury. Knee Surg Sports Traumatol Arthrosc 2015;23:3044-8.

Copyright 2021 BMJ Publishing Group. All rights reserved. For permission to reuse any of this content visit

https://www.bmj.com/company/products-services/rights-and-licensing/permissions/

BMJ Case Report Fellows may re-use this article for personal use and teaching without any further permission.

Become a Fellow of BMJ Case Reports today and you can:

- Submit as many cases as you like

- Enjoy fast sympathetic peer review and rapid publication of accepted articles

- Access all the published articles

Re-use any of the published material for personal use and teaching without further permission

Customer Service

If you have any further queries about your subscription, please contact our customer services team on +44 (0) 2071111105 or via email at support@bmj.com.

Visit casereports.bmj.com for more articles like this and to become a Fellow 